\title{
Immediate-Early Gene Induction and MAP Kinase Activation during Recovery from Metabolic Inhibition in Cultured Cardiac Myocytes
}

\author{
Atsushi Yao, Toshiyuki Takahashi, Teruhiko Aoyagi, Koh-ichiro Kinugawa, Osami Kohmoto, Seiryo Sugiura, \\ and Takashi Serizawa \\ The Second Department of Internal Medicine, Faculty of Medicine, University of Tokyo, Tokyo 113, Japan
}

\section{Abstract}

To investigate how cardiac myocytes recover from a brief period of ischemia, we used a metabolic inhibition (MI) model, one of the in vitro ischemic models, of chick embryo ventricular myocytes, and examined the induction of immediate-early (IE) genes mRNAs and the activity of mitogenactivated protein (MAP) kinase. We performed Northern blot analysis to study the expression of $c$-jun, $c$-fos, and cmyc mRNAs during MI using $1 \mathrm{mM} N \mathrm{NaCN}$ and $20 \mathrm{mM}$ 2deoxy-d-glucose, and also during the recovery from MI of $30 \mathrm{~min}$. The c-fos mRNA was induced transiently at 30 and $60 \mathrm{~min}$ during the recovery. The expression of c-jun mRNA was significantly augmented at $30,60,90$, and 120 min during the recovery (3.0-, 4.7-, 2.4-, and 1.9 -fold induction, respectively) and so did the expression of c-myc mRNA (1.4-, 1.7-, 1.8-, and 2.0-fold induction, respectively). In contrast, the levels of these mRNAs remained unchanged during MI. The electrophoretic mobility shift assay revealed that AP-1 DNA binding activity markedly increased at $120 \mathrm{~min}$ during the recovery. When the cells were pretreated with protein kinase C (PKC) inhibitors, $100 \mu \mathrm{M}$ H-7 or $1 \mu M$ staurosporine, the induction of c-jun mRNA at 60 min during the recovery was markedly suppressed (95 or $82 \%$ reduction, respectively). The c-jun induction was partially inhibited when the cells were treated with 2 mM EGTA during MI and the recovery ( $42 \%$ reduction). MAP kinase activity quantified with in-gel kinase assay was unchanged during MI, but significantly increased at 5,10 , and 15 min during the recovery (3.0-, 4.1-, and 3.4 -fold increase, respectively). S6 kinase activity was also augmented significantly at 15 min during the recovery. Thus, these data suggest that IE genes as well as MAP kinase may play roles in the recovery process of cardiac myocytes from MI, and that the augmentation of c-jun expression needs the activation of PKC and to some extent, $\left[\mathrm{Ca}^{2+}\right]_{\mathrm{i}}$. (J. Clin. Invest. 1995. 96:69-77.) Key words: immediate-early gene $\cdot$ MAP kinase $\bullet$ metabolic

This study was presented in part at the 66th Scientific Sessions of the American Heart Association, Atlanta, GA, November 8-11, 1993, and published in abstract form (Circulation, 1993; 88 [ suppl. I]:I-543).

Address correspondence to Atsushi Yao, M.D., The Second Department of Internal Medicine, Faculty of Medicine, University of Tokyo, 7-3-1 Hongo, Bunkyo-ku,Tokyo, 113, Japan. Phone: 3-3815-5411 ext. 3076; FAX: 3-3814-0021.

Received for publication 24 May 1994 and accepted in revised form 13 March 1995.

J. Clin. Invest.

(c) The American Society for Clinical Investigation, Inc.

0021-9738/95/07/0069/09 \$2.00

Volume 96 , July $1995,69-77$ inhibition • protein kinase $\mathrm{C} \cdot$ chick embryo cardiac myocytes

\section{Introduction}

Myocardial ischemia causes a variety of damages in cardiac myocytes. These ischemic damages result in cardiac pump failure and poor prognosis in patients with ischemic heart disease. A prolonged period of ischemia induces myocardial necrosis, which may decrease the number of contracting myocytes because matured cardiac myocytes are terminally differentiated cells and cannot divide anymore. After myocardial infarction after a prolonged ischemia, a massive myocardial necrosis, and a reconstructing process called "ventricular remodeling" occurs. This ventricular remodeling may be an adaptive process to the loss of myocytes, and consists of hypertrophy of the remaining cardiocytes. On the other hand, the remodeling provokes a further ventricular dysfunction and high mortality as well as morbidity $(1,2)$. In contrast to the prolonged ischemia, cardiac myocytes can recover from a brief period of ischemia, although persistent myocardial depression called "myocardial stunning' may follow the ischemic insults. During the recovery after the brief ischemia, cardiac myocytes adjacent to the injury show prominent nucleoli, indicating active protein synthesis (3). Moreover, a clinical study showed that repetitive transient ischemia caused hypertrophy of cardiac myocytes in ischemic segments (4). However, molecular mechanisms underlying these active recovery processes remain to be elucidated.

Until now, intracellular molecular mechanisms of cardiac adaptation have been examined exclusively in in vivo and in vitro hypertrophic responses. Many growth factors (5), pressure overload (6-8), and stretch stimulation (9) have been shown to lead myocardial hypertrophy through the activation of multiple signaling pathways proceeding to the induction of the immediate-early (IE) ${ }^{1}$ genes. As to the response to growth factors, it is clear that the first event is the binding of the growth factors to their specific receptors, which was followed by the activation of various intracellular signal transduction pathways. Since it was reported that cardiac hypertrophy was induced by $\alpha_{1}$-adrenergic stimulation and associated with the expression of the cmyc gene (10), various cellular proto-oncogenes have been reported to play roles in cardiac hypertrophy as transcriptional factors. AP-1 proteins such as c-Jun and c-Fos were reported to become homo- or hetero-dimerized to bind to the specific sequence (AP-1 site) in the enhancers of the various genes and

1. Abbreviations used in this paper: BSS, balanced salt solution; EMSA, electrophoretic mobility shift assay; IE, immediate-early; MAP, mitogen activated protein; MI, metabolic inhibition; PKA, protein kinase A; PKC, protein kinase C; SSC, standard sodium citrate; TBS, tris-buffered saline. 
then regulate their expression (11-13). The genes containing an AP-1 site include cardiac genes such as skeletal $\alpha$-actin (14), myosin light chain (15), atrial natriuretic peptide $(16,17)$, and TGF- $\beta$ (18). On the other hand, in a recent study (9) using a stretch model of cultured cardiac myocytes, in which the cardiac hypertrophic responses occurred, multiple signaling pathways such as protein kinase $\mathrm{C}$ (PKC) cascade, tyrosine-kinase cascade, and MAP kinase cascade were shown to be activated. The expression of IE genes was also increased and then protein synthesis was accelerated. These data suggest that both the induction of IE genes and the activation of the protein kinase cascades were early intracellular events in response to growth stimuli in cardiac myocytes.

In brain (19), and kidney $(20,21)$, the induction of IE genes was also documented as an early response to ischemia and/or reperfusion. In hearts there have been a few reports concerning the induction of IE genes during ischemia and reperfusion. Using an in vivo ischemia model of pig hearts, Brand et al. (22) reported that $c$-jun, junB, c-fos, and egr-l were significantly induced not in the nonischemic area but in the ischemic area after reperfusion. In this study, ischemia and/or reperfusion were suggested as main stimuli to cardiac myocytes. However, it is not clear what is the first signaling event and how cardiac myocytes recover from ischemic damages by themselves, that is, without any influences from the outside such as paracrine or hemodynamic effects. In another study, using an in vitro hypoxia model of cultured rat cardiac myocytes, Webster et al. (23) demonstrated that $c$-jun, jun D, and c-fos mRNAs were significantly induced during exposure to hypoxia, and the induction of c-jun and c-fos mRNAs was repressed by blockers for protein kinase A (PKA) or PKC. Their study was the first report that examined kinase cascades, but they did not investigate the molecular responses to reoxygenation in cardiac myocytes.

Accordingly, the objective of this study was to elucidate the intracellular mechanism how cardiac myocytes recover from ischemia. Using a metabolic inhibition (MI) model of cultured 10-d chick embryo ventricular myocytes, which is one of the in vitro ischemia models, we examined $(a)$ whether and when the induction of IE genes and/or the activation of MAP kinase and S6 kinase would occur during MI and during the recovery from MI; $(b)$ if IE genes were induced, which intracellular signals would contribute to their induction; and $(c)$ whether augmented bindings of the IE gene products to specific DNA sequences would actually occur during these processes.

\section{Methods}

\section{Primary culture of chick embryo ventricular myocytes}

Spontaneously contracting chick embryo ventricular cells were prepared according to the previous method (24). Briefly, ventricles from 10-dold chick embryos were removed, minced, and digested in $37^{\circ} \mathrm{C}$ Hank's solution including $0.025 \%$ trypsin. Digestion of four cycles was performed and cells in the supernatant from each cycle were placed into cold trypsin inhibitor solution ( $50 \%$ heat inactivated fetal calf serum and $50 \%$ Hank's solution). The resulting cell suspension was centrifuged at 2,500 rpm for $10 \mathrm{~min}$. Supernatant was discarded and the cells were resuspended in culture medium consisting of $6 \%$ fetal calf serum (GIBCO BRL, Gaithersburg, MD), 40\% Medium 199 (GIBCO BRL), $0.1 \%$ penicillin-streptomycin solution, $2.7 \mathrm{mM}$ glucose, and $54 \%$ balanced salt solution (BSS) containing $116 \mathrm{mM} \mathrm{NaCl}, 1.0 \mathrm{mM} \mathrm{NaH}_{2} \mathrm{PO}_{4}$, $0.8 \mathrm{mM} \mathrm{MgSO}, 1.18 \mathrm{mM} \mathrm{KCl}, 0.87 \mathrm{mM} \mathrm{CaCl}_{2}$, and $26.2 \mathrm{mM}$ $\mathrm{NaHCO}_{3}$. The cell suspension was diluted to $5 \times 10^{5}$ cells $/ \mathrm{ml}$ and placed in 35-mm culture dishes for ATP measurement, $60-\mathrm{mm}$ culture dishes for RNA preparation, nuclear protein extraction, MAP kinase assay, and S6 peptide kinase assay, or in 100-mm culture dishes with $25-\mathrm{mm}$ circular cover slips on the bottom for intracellular calcium ion measurement. Cells in the dishes were incubated in a 5\% $\mathrm{CO}_{2}-95 \%$ air atmosphere at $37^{\circ} \mathrm{C}$ for $3 \mathrm{~d}$. Culture medium in each dish was exchanged to serum-free medium consisting of $20 \%$ Medium 199, 20\% Hams F12 (GIBCO BRL), $54 \% \mathrm{BSS}, 0.6 \mathrm{mM} \mathrm{KCl}$, and $21 \mathrm{mM}$ glucose, and then cells were incubated in the same condition for $24 \mathrm{~h}$.

\section{RNA isolation and Northern blot analysis}

Cells at the specific time point were washed with ice-cold PBS $(-)$ twice and harvested with a rubber policeman in $1.8 \mathrm{ml}$ of $4 \mathrm{M}$ guanidinium isothiocyanate solution. Total cellular RNA was isolated from the cell lysates with the acid guanidinium isothiocyanate method (25). Aliquots $(20 \mu \mathrm{g})$ of total RNA were size-separated by electrophoresis in $1 \%$ agarose-3\% formaldehyde gels and transferred to nylon membranes (Zeta-Probe blotting membrane; Bio-Rad laboratories, Richmond, CA) in $10 \times$ standard sodium citrate (SSC; $1 \times=0.15 \mathrm{M}$ sodium chloride and $0.015 \mathrm{M}$ sodium citrate). Membranes were prehybridized in the solution mix consisting of $40 \%$ formamide, $5 \times$ SSC, $5 \times$ Denhardt's solution, $0.5 \%$ sodium dodecyl sulfate (SDS), $20 \mathrm{mM} \mathrm{NaH}_{2} \mathrm{PO}_{4}$ (pH 7.2), $100 \mu \mathrm{g} / \mathrm{ml}$ sonicated salmon sperm DNA, at $42^{\circ} \mathrm{C}$, for $12-16 \mathrm{~h}$. They were then hybridized in the newly prepared solution mix for 12 $16 \mathrm{~h}$ with 1.8-kb EcoRI fragment of the rat c-jun cDNA pUC9, 0.26kb SacI-PstI fragment of chicken $v$-fos (gift from Dr. H. Iba) (26), 0.97-kb ClaI-PstI fragment of avian $v$-myc (Takara Shuzou, Kyoto, Japan), and 0.4-kb Hinf I fragment of human $\beta$-actin (Wako, Osaka, Japan) labeled with ${ }^{\mathrm{T}}$ Quick prime ${ }^{\mathrm{TM}}$ kit (Pharmacia, LKB) and $\left[{ }^{32} \mathrm{P}\right]-$ dCTP $(3,000 \mathrm{Ci} / \mathrm{mmol}$; NEN, Dupont, Boston, MA). The membranes were washed stringently with the final wash in $0.5 \times \mathrm{SSC} / 0.1 \%$ SDS, at $55^{\circ} \mathrm{C}$, for $30 \mathrm{~min}$. The blots were then exposed to $\mathrm{x}$-ray films (New RX; Fuji Film, Kanagawa, Japan) with intensifying screens at $-80^{\circ} \mathrm{C}$ for $24-72 \mathrm{~h}$.

\section{Nuclear protein extraction}

Nuclear extracts were obtained according to the previously described method (27). Briefly, after each intervention, cells were washed with $5 \mathrm{ml} \mathrm{pH} \mathrm{7.4} \mathrm{Tris-buffered} \mathrm{saline} \mathrm{(TBS),} \mathrm{homogenated} \mathrm{in} 5 \mathrm{ml} \mathrm{TBS,} \mathrm{and}$ pelleted at $1,500 \mathrm{~g}$ for $5 \mathrm{~min}$. The pellets were resuspended in $1 \mathrm{ml}$ TBS, transferred into Eppendorf tubes, and pelleted again by spinning for 15 $\mathrm{s}$ in a microfuge. After removal of TBS, the pellets were resuspended in $400 \mu \mathrm{l}$ ice-cold buffer $\mathrm{A}$ ( $10 \mathrm{mM}$ Hepes pH $7.9,10 \mathrm{mM} \mathrm{KCl}, 0.1$ mM EDTA, $0.1 \mathrm{mM}$ EGTA, $1 \mathrm{mM}$ DTT, $0.5 \mathrm{mM}$ PMSF) by gentle pipetting. The cells were allowed to swell on ice for $15 \mathrm{~min}$, after which $25 \mu \mathrm{l}$ of a $10 \%$ Nonidet NP-40 (Fluka) was added and the tubes were vigorously vortexed for $10 \mathrm{~s}$. The homogenates were centrifuged for $30 \mathrm{~s}$ in a microfuge. After removal of the supernatants, the pellets containing nuclear protein were resuspended in $50 \mu$ lice-cold buffer B $(20 \mathrm{mM}$ Hepes pH 7.9, $0.4 \mathrm{M} \mathrm{NaCl}, 1 \mathrm{mM}$ EDTA, 1 mM EGTA, 1 mM DTT, $1 \mathrm{mM}$ PMSF), and the tubes were vigorously rocked at $4^{\circ} \mathrm{C}$ for $5 \mathrm{~min}$ on a shaking platform. The nuclear extracts were centrifuged for $5 \mathrm{~min}$ in a microfuge at $4^{\circ} \mathrm{C}$ and the supernatants were saved. Aliquots $(5 \mu \mathrm{l})$ of each supernatant were used for the electrophoretic mobility shift assay.

\section{Electrophoretic mobility shift assay (EMSA)}

Using GelShift ${ }^{\mathrm{TM}}$ Assay Kit (Stratagene), we examined the transcriptional activity of AP-1 proteins. At first, double strand DNA fragments containing AP-1consensus lesion (AP-1 probe), the sequence of which were 5'-CTAGTGATGAGTCAGCCGGATC-3', were labeled with $\gamma$ [ $\left.{ }^{32} \mathrm{P}\right]$ ATP $(6,000 \mathrm{Ci} / \mathrm{mM}$; NEN Dupont, Boston, MA). After $17 \mu \mathrm{l}$ of incubation buffer included in the kit, 1-3 $\mu \mathrm{l}$ of the labeled AP-1 probe solution, and $5 \mu \mathrm{l}$ of the nuclear protein solution as described above were mixed and then incubated at room temperature for $30 \mathrm{~min}$, the mixtures with $2 \mu \mathrm{l}$ of $0.1 \%$ bromphenol blue dye were electrophoresed at $4^{\circ} \mathrm{C}$ in $5 \%$ polyacrylamide gel. The gels were exposed to $\mathrm{x}$-ray films 
(New RX; Fuji Film, Kanagawa, Japan) for 12-24 h and the $\mathrm{x}$-ray films were developed.

\section{MAP kinase in-gel kinase assay}

MAP kinase activity was measured according to the previously described method (28). Briefly, the cells at the specific time point were washed with ice-cold PBS $(-)$ twice and harvested with a rubber policeman in $1.2 \mathrm{ml}$ of MAP lysis buffer containing $25 \mathrm{mM}$ Tris- $\mathrm{HCl}(\mathrm{pH}$ 7.4), $25 \mathrm{mM} \mathrm{NaCl}, 10 \mathrm{mM} \mathrm{NaF}, 10 \mathrm{mM} \mathrm{Na} \mathrm{P}_{2} \mathrm{O}_{7}, 0.5 \mathrm{mM}$ EGTA, 1 $\mathrm{mM} \mathrm{Na} \mathrm{VO}_{4}, 10 \mathrm{nM}$ okadaic acid, $1 \mathrm{mM}$ PMSF, $1.6 \mu \mathrm{M}$ leupeptin, $1.5 \mathrm{nM}$ aprotinin, and $38 \mathrm{mM} p$-nitrophenyl phosphate. The cell-free lysates were prepared from the cell lysates obtained. Aliquots $(20 \mu \mathrm{l})$ of the cell-free lysates were mixed with $5 \mu \mathrm{l}$ of $5 \times$ loading buffer, which consisted of $62.5 \mathrm{mM}$ Tris $\mathrm{HCl}(\mathrm{pH} \mathrm{6.8)}, 2 \%$ SDS, $1 \% 2$ mercaptoethanol, $10 \%$ glycerol, $0.002 \%$ bromphenol blue, and were then electrophoresed in $10 \%$ SDS-polyacrylamide gels containing 0.5 $\mathrm{mg} / \mathrm{ml}$ myelin basic protein. After electrophoresis, the gels were washed twice (30 min each) in an enzyme-denature solution containing $6 \mathrm{M}$ guanidine- $\mathrm{HCl}$ and 5 times ( $10 \mathrm{~min}$ each) in a protein-renature solution containing $5 \mathrm{mM} 2$-mercaptoethanol, $50 \mathrm{mM}$ Tris, and $0.04 \%$ Tween 40. The proteins in the gels were then incubated in $30 \mathrm{ml}$ of phosphorylation buffer containing $40 \mathrm{mM}$ Hepes ( $\mathrm{pH} 8.0$ ), $0.5 \mathrm{mM}$ EGTA, $10 \mathrm{mM}$ $\mathrm{MgCl}_{2}, 2 \mu \mathrm{M}$ protein kinase inhibitor (rabbit sequence; Sigma Chemical Co., St. Louis, MO), $40 \mu \mathrm{M}$ ATP, and $2.5 \mu \mathrm{Ci} / \mathrm{ml} \gamma-\left[{ }^{32} \mathrm{P}\right]$ ATP $(6,000$ $\mathrm{Ci} / \mathrm{mM}$; Dupont-NEN, Boston, MA), for $1 \mathrm{~h}$ at room temperature and the gels were washed several times in a washing solution containing $5 \%$ trichloroacetic acid and $1 \% \mathrm{Na}_{4} \mathrm{P}_{2} \mathrm{O}_{7}$ until radioactivity of the solution became negligible. After the washes, the autoradiography was performed on the dried gels with intensifying screens at $-80^{\circ} \mathrm{C}$ for $24 \mathrm{~h}$ and the films were developed.

\section{Western blot analysis}

The cell-free lysates were prepared from the cell lysates harvested in $1.2 \mathrm{ml}$ of MAP lysis buffer according to the method of MAP kinase ingel kinase assay described above. Aliquots $(20 \mu \mathrm{l})$ of them were mixed with $5 \mu \mathrm{l} 5 \times$ loading buffer and electrophoresed in 10\% SDS-PAGE. After electrophoresis, the proteins separated in the gel were electrically transferred to a Clear Blot P membrane (ATTO Corporation, Tokyo, Japan) with semi-dry method and the blot was blocked at room temperature in TBS ( $\mathrm{pH} 7.4$ ) containing 3\% ovalbumin overnight. The blot was then incubated in TBS containing $1 \%$ Triton X, $0.3 \%$ ovalbumin and 2 $\mu \mathrm{g} / \mathrm{ml}$ polyclonal antibodies against MAP kinase (UBI) obtained from rabbit for $1 \mathrm{~h}$. After subjected to appropriate washes in TBS containing $1 \%$ Triton $\mathrm{X}$ and $0.3 \%$ ovalbumin, the blot was also incubated in TBS containing $1 \%$ Triton $X, 0.3 \%$ ovalbumin and 1:3,000 diluted second antibodies (goat anti-rabbit or anti-mouse IgG conjugated to horseradish peroxidase provided by ECL) for $30 \mathrm{~min}$. After this incubation, the blot was washed three times (30-, 15-, and 10-min), and exposed to xray films (New RX; Fuji Film, Kanagawa, Japan) by the chemiluminescence method (ECL). The x-ray films were then developed.

\section{S6 peptide kinase assay}

S6 peptide kinase assay was performed with a previously described method (29). Aliquots $(100 \mu \mathrm{l})$ of the cell free lysates harvested in $200 \mu \mathrm{l}$ of MAP lysis buffer as described above were incubated with 5 $\mu \mathrm{g}$ of polyclonal anti-rat rsk kinase antibody (UBI) for $2 \mathrm{~h}$ on ice. After that, the mixture with $100 \mu \mathrm{l}$ of 5\% protein A-Sepharose was incubated for $60 \mathrm{~min}$ rotated at $4^{\circ} \mathrm{C}$ and then centrifuged at $14,000 \mathrm{rpm}$ for $15 \mathrm{~s}$. The pellets obtained were washed three times with MAP lysis buffer containing $1 \%$ Triton $\mathrm{X}$ and resuspended in $25 \mu \mathrm{l}$ of MAP lysis buffer. The prepared samples were mixed with 2.5 volume of reaction buffer consisting of $50 \mathrm{mM}$ MOPS ( $\mathrm{pH} 7.2$ ), $120 \mathrm{mM}$ beta-glycerophosphate, $60 \mathrm{mM} p$-nitrophenylphosphate, $10 \mathrm{mM}$ EGTA, $30 \mathrm{mM} \mathrm{MgCl}_{2}$, $2 \mathrm{mM}$ DTT, $2 \mathrm{mM}$ sodium orthovanadate, $2 \mu \mathrm{M}$ PKI, $50 \mu \mathrm{M}$ ATP, 0.5 mM S6 peptide, and $5 \mu \mathrm{Ci} \gamma-\left[{ }^{32} \mathrm{P}\right]-\mathrm{ATP}(6,000 \mathrm{Ci} / \mathrm{mM}$; NEN, Dupont, $\mathrm{MA}$ ), and incubated for $15 \mathrm{~min}$ at $30^{\circ} \mathrm{C}$. The mixed samples were dropped onto $2.5-\mathrm{cm}$ circular Whatman P81 phosphocellulose papers. The samples on the papers were washed five times with $0.5 \%$ phosphoric acid and once with $95 \%$ ethanol. The radio-activity of papers in scintillation vials were counted with Cerenkov method.

\section{Measurement of $\left[\mathrm{Ca}^{2+}\right]_{i}$}

$\left[\mathrm{Ca}^{2+}\right]_{\mathrm{i}}$ was measured with $\mathrm{Ca}^{2+}$ fluorescence dye indo-1 as previously described $(30,31)$. Briefly, the loading stocks of $100 \mu \mathrm{M}$ indo-1 acetoxymetyl ester (indo-1/AM; Dojin Kagaku, Kumamoto, Japan) consisting of $8.79 \mathrm{ml}$ of fetal calf serum, $210 \mu \mathrm{l}$ of $25 \%$ Pluronic F127 (wt/wt in dimethyl sulfoxide), and $1 \mathrm{mM}$ indo-1/AM in dimethyl sulfoxide were prepared by sonication. The loading stocks were diluted in the serumfree media up to $5 \mu \mathrm{M}$ indo-1/AM concentration. Cells on the coverslip in 100-mm dishes were moved in the diluted dye solution to be incubated in a $5 \% \mathrm{CO}_{2}-95 \%$ air at $37^{\circ} \mathrm{C}$ for $15 \mathrm{~min}$, and then washed in dye-free serum free medium in the same condition for $5 \mathrm{~min}$. After that, the cells were placed in the flow-through chamber. While the indo-1-loaded cells were continuously superfused with media being bubbled with $5 \% \mathrm{CO}_{2}-$ 95\% air and kept at $37^{\circ} \mathrm{C}$, fluorescence from the cells was being measured with the previously-described system $(30,31)$. This system uses a high-pressure mercury-arc lamp providing intense emission peak at $360 \mathrm{~nm}$. The cells loaded with Indo-1/AM in a flow-through chamber, were illuminated via epifluorescence optics using a Fluor $40 \times$ objective lens. Fluorescence was collected and divided with a dichroic mirror to permit a simultaneous measurement of 410 - and $480-\mathrm{nm}$ wavelengths. The ratio (R) of 410-nm fluorescence intensity/480-nm fluorescence intensity was used as an indicator of $\left[\mathrm{Ca}^{2+}\right]_{\mathrm{i}} \cdot\left[\mathrm{Ca}^{2+}\right]_{\mathrm{i}}$ was calculated with the following formula, $\left[\mathrm{Ca}^{2+}\right]_{\mathrm{i}}=250 \times \beta \times\left(R-R_{\min }\right) /\left(R_{\max }-R\right)$. In chick embryo ventricular myocytes, the calculated variables were: $R_{\min }=0.40, R_{\max }=1.77, \beta=2.27$.

\section{ATP measurement}

The intracellular ATP content was measured with high performance liquid chromatography (32). Cells at specific time points were frozen in liquid nitrogen, and subsequently scraped in $1 \mathrm{ml}$ of ice-cold $0.7 \mathrm{~N}$ $\mathrm{HClO}_{4}$. The cell lysates were quickly transferred into 2-ml eppendorf tubes on ice and sonicated. After addition of $1 \mathrm{ml}$ ice-cold $\mathrm{H}_{2} \mathrm{O}$, the cell lysates were vortexed and divided into two separate eppendorf tubes. One was mixed on ice with $60 \mu \mathrm{l}$ of ice-cold $1.5 \mathrm{M} \mathrm{K}_{2} \mathrm{HPO}_{4}$, and the other was set aside for subsequent measurement of protein content. The mixed samples were centrifuged at $3,300 \mathrm{rpm}$ for $20 \mathrm{~min}$ at $4^{\circ} \mathrm{C}$. After centrifugation, an aliquot $(10 \mu \mathrm{l})$ of the supernatant was placed on a reversed-phase column $(4.6 \times 250 \mathrm{~mm}$, STR ORS-H; Shimazu Inc., Japan) and eluted at a flow rate of $1 \mathrm{ml} / \mathrm{min}$ with a buffer containing $215 \mathrm{mM} \mathrm{KH}_{2} \mathrm{PO}_{4}, 2.3 \mathrm{mM}$ tetrabutylammonium hydrogen sulphate and $3.5 \%$ acetonitrile $(\mathrm{pH} 6.25)$. The column effluent was analyzed with a spectrophotometer (SPD6A, Shimazu Inc., Japan) at $260 \mathrm{~nm}$ to quantify the ATP content by measuring each peak area. Protein content was determined by the Lowry's method (33). Each ATP content was calculated as $\mathrm{nmol} / \mathrm{mg}$ protein and expressed as a ratio to the control level.

\section{Experimental protocol}

Metabolic inhibition. For MI, the serum-free medium in each dish was taken away and cells were quickly rinsed once with the MI medium consisting of the serum-free medium containing $1 \mathrm{mM} \mathrm{NaCN}$ and 20 $\mathrm{mM}$ 2-deoxy-d-glucose instead of $21 \mathrm{mM}$ glucose. After the rinse of the cells, $4 \mathrm{ml}$ of the MI medium was poured in each dish again. The first addition of the MI medium was regarded as the starting point of MI. Cells in the MI medium were incubated in the same condition for a pre-determined duration. At the end of each predetermined period, the MI medium was removed and the cells were harvested for the various measurements as described above. The time point of pouring ice-cold PBS(-) into each dish was defined as the end point of MI. Lysates from the cells without MI stress were assigned as the control.

Recovery phase after MI. After the cells were incubated in the MI medium for $30 \mathrm{~min}$ in accordance with the MI protocol as described above, the MI medium was discarded and the cells were quickly rinsed once with the serum-free medium. This time point of the rinsing was defined as the starting point of the recovery phase. The serum-free 


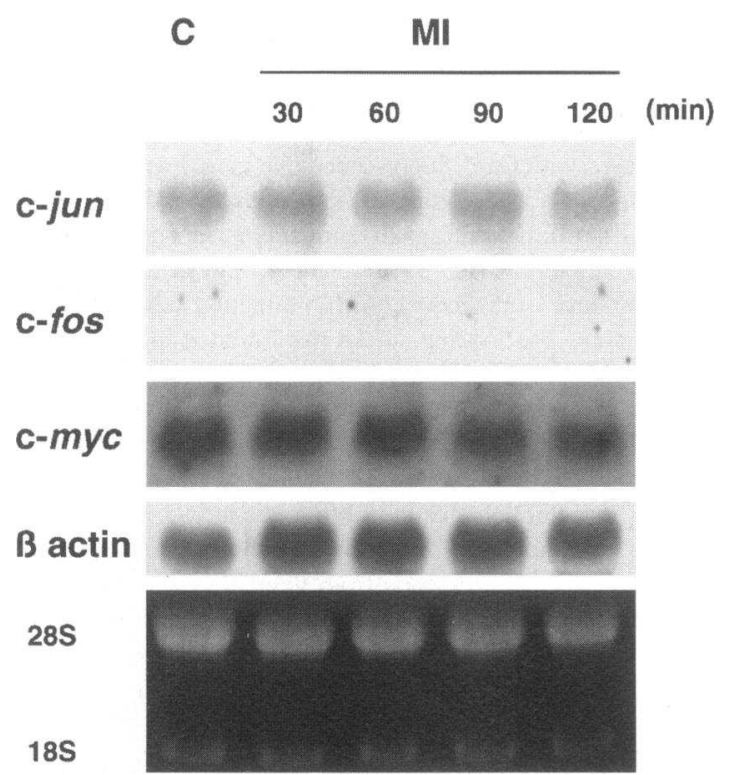

Figure 1. Representative results of Northern blot analysis of IE gene expression during the MI. During MI, the levels of c-jun, c-fos, and c-myc mRNAs were unchanged as compared with the control $(C)$ levels. The $\beta$-actin signals and the ethidium bromide-stained pictures of $28 \mathrm{~S}$ ribosomal RNAs are shown as internal controls to assure the quality and quantity of RNA loaded and transferred on each lane.

medium was then quickly added to the cells in each dish again. The cells were then incubated in the same condition for a pre-determined duration, and cell lysates were obtained as described above. Furthermore, $\left[\mathrm{Ca}^{2+}\right]_{\mathrm{i}}$ was recorded with indo- 1 before MI, and during MI of $30 \mathrm{~min}$ and the subsequent recovery phase.

Effects of pretreatment with protein kinase inhibitors. From $30 \mathrm{~min}$ before MI, cells were pretreated with protein kinase $\mathrm{C}$ (PKC) inhibitors such as $100 \mu \mathrm{M} \mathrm{H-7} \mathrm{(=1-[5-isoquinolinylsulfonyl]-2-methyl-pipera-}$ zine) and $1 \mu \mathrm{M}$ staurosporine, protein kinase A (PKA) inhibitor (10 $\mu \mathrm{M} \mathrm{H}-89=\mathrm{N}-[(p$-bromocinnamylamino $)$ ethyl $]-5$-isoquinolinesulfonamide) or calmodulin kinase inhibitor $(10 \mu \mathrm{M}$ W-7 $=\mathrm{N}-[6-$ aminohexyl]-5-chloro-1-naphthalenesulfonamide hydrochloride). MI of $30 \mathrm{~min}$ was then imposed on the cells with the MI medium and the cells were allowed to recover for $60 \mathrm{~min}$ with the serum-free medium. Both of the media also contained the same concentration of one of the protein kinase inhibitors. The cell lysates obtained were prepared for Northern blot analysis of c-jun mRNA.

EGTA protocol. With the serum-free medium and the MI medium both of which contained $2 \mathrm{mM}$ EGTA, cells were exposed to MI of 30 min with the subsequent recovery phase of $60 \mathrm{~min}$. The effects of chelating extracellular $\mathrm{Ca}^{2+}$ with EGTA on $\left[\mathrm{Ca}^{2+}\right]_{\mathrm{i}}$ and c-jun expression were examined.

Through these protocols, all the media were incubated in a $5 \% \mathrm{CO}_{2}-$ $95 \%$ air atmosphere at $37^{\circ} \mathrm{C}$ for $2 \mathrm{~h}$ just before the use, and their resulting $\mathrm{pH}$ was between 7.35-7.45. Because of the instability of $\mathrm{NaCN}$ and protein kinase inhibitors, these agents were diluted in the pre-incubated media from the freshly prepared concentrates at $30 \mathrm{~min}$ before the use.

\section{Data analysis}

The relative abundance of IE gene mRNAs and the relative activity of MAP kinase were quantitated by laser densitometry. The densitometric data were normalized by calculating the ratio of the densitometric values of RNA or MAP kinase activity to those of the control samples.

\section{Statistics}

Values are expressed as mean \pm SEM. Differences in the means among the groups were tested by two-way analysis of variance where appro-

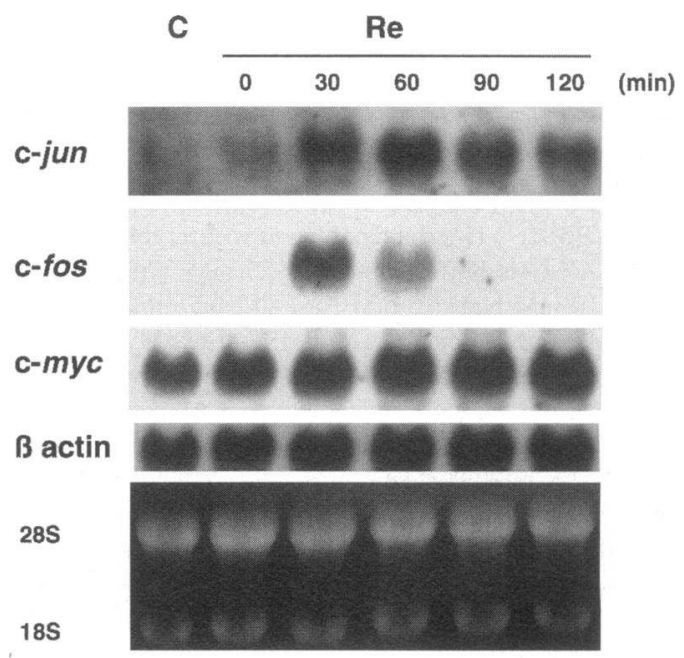

Figure 2. Representative results of Northern blot analysis of IE gene expression during the recovery $(R e)$ from the MI. During Re, the expression of c-jun mRNA increased at $30 \mathrm{~min}$ and peaked around $60 \mathrm{~min}$. The increase in c-jun mRNA persisted at least to $120 \mathrm{~min}$ after the beginning of Re. The induction of c-fos mRNA was transiently observed at 30 and 60 min during Re. The expression of c-myc mRNA was distinctly observed at the control $(C)$, and increased gradually during $\operatorname{Re}$ of $120 \mathrm{~min}$. The $\beta$-actin signals and the ethidium bromide-stained pictures of $28 \mathrm{~S}$ ribosomal RNAs are shown as internal controls.

priate. If the $\mathrm{F}$ test showed an overall significance, comparison of the two groups was performed by Student's unpaired $t$ test. $P$ values $<0.05$ were considered as statistically significant.

\section{Results}

Expression of immediate-early gene mRNAs. Northern blot analysis and the following densitometry showed that the levels of c-jun and c-myc mRNAs remained unchanged and c-fos mRNA was not detected for $2 \mathrm{~h}$ during MI (Fig.1). In contrast, significant increases in c-jun and c-myc mRNAs were observed at 30,60, 90, and $120 \mathrm{~min}$ during the recovery from MI (Fig. 2, densitometric values of c-jun mRNA were $3.0 *, 4.7 *, 2.4 *$, and $1.9^{\dagger}$ - fold induction compared with the control levels, respectively, and those on c-myc mRNA were $1.4^{*}, 1.7^{*}, 1.8^{*}$, and $2.0 *$-fold induction compared with the control levels, $n$ $=3, * P<0.01,{ }^{\dagger} P<0.05$, respectively). On the other hand, Northern blot analysis demonstrated a transient induction of c- fos mRNA at 30 and 60 min during the recovery from MI (Fig. 2).

Effect of $\left[\mathrm{Ca}^{2+}\right]_{i}$ on the induction of $c$-jun mRNA. Previous studies $(31,34)$ have reported that during MI $\left[\mathrm{Ca}^{2+}\right]_{\mathrm{i}}$ was gradually rising over the normal systolic level in cardiac myocytes. To make it clear whether this MI-induced calcium rise was associated with the induction of c-jun mRNA during the recovery from $\mathrm{MI}$, we tried to prevent $\left[\mathrm{Ca}^{2+}\right]_{\mathrm{i}}$ from rising and keep it under the diastolic $\left[\mathrm{Ca}^{2+}\right]_{\mathrm{i}}$ level. As shown in a of Fig. $3,\left[\mathrm{Ca}^{2+}\right]_{\mathrm{i}}$ measured with indo-1 gradually increased from $314 \pm 28 \mathrm{nM}$ at $5 \mathrm{~min}$ during MI, when the cells already stopped beating, to $1658 \pm 289 \mathrm{nM}$ at 30 min during $\mathrm{MI}(n=3)$ and rapidly decreased during the recovery. On the other hand, the intracellular ATP content rapidly decreased to $10 \%$ of the control levels and remained below this low level throughout MI ( $n$ $=5$ ). After MI of $30 \mathrm{~min}$, the intracellular ATP content gradu- 


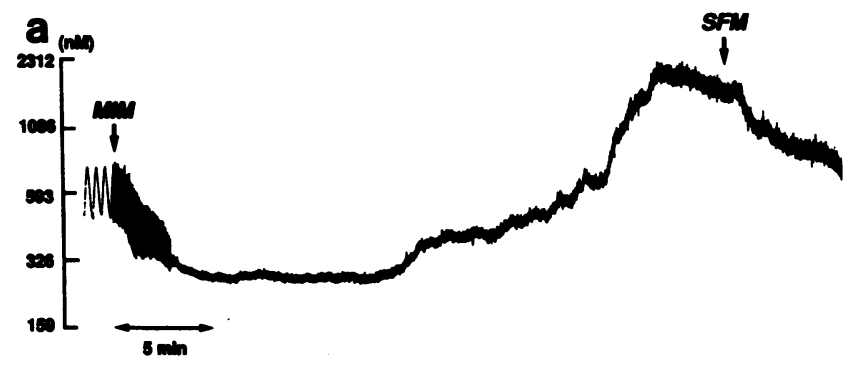

b mintate EOTA

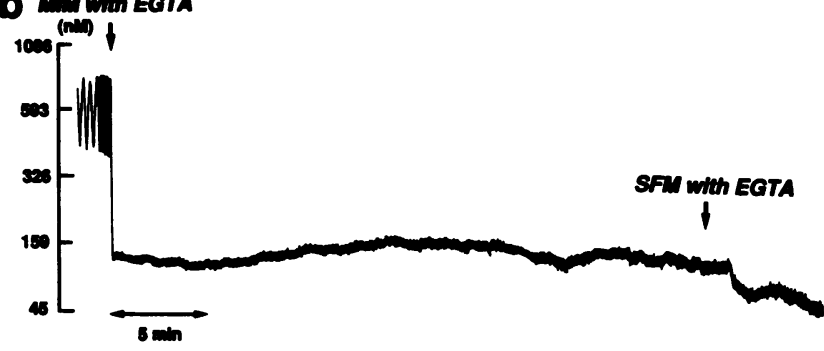

Figure 3. $\left[\mathrm{Ca}^{2+}\right]_{\mathrm{i}}$ transient during $\mathrm{MI}$ and the recovery $(\mathrm{Re})$ from MI. After addition of metabolic inhibition medium (MIM) consisting of serum-free medium (SFM) containing $1 \mathrm{mM} \mathrm{NaCN}$ and $20 \mathrm{mM} 2-$ deoxy-d-glucose instead of $21 \mathrm{mM}$ glucose, $\left[\mathrm{Ca}^{2+}\right]_{\mathrm{i}}$ lost its variation due to spontaneous beating and decreased below the diastolic level of the beating myocytes at once down to $314 \pm 28 \mathrm{nM}$ and gradually increased beyond the systolic level up to $1658 \pm 289 \mathrm{nM}$ at $30 \mathrm{~min}$ during MI (a). On the other hand, after addition of MIM with 2 mM EGTA, $\left[\mathrm{Ca}^{2+}\right]_{\mathrm{i}}$ decreased below the diastolic level at once down to $168 \pm 26$ $\mathrm{nM}$, and remained unchanged during $\mathrm{MI}$. $\left[\mathrm{Ca}^{2+}\right]_{\mathrm{i}}$ at 30 min during $\mathrm{MI}$ was $184 \pm 26 \mathrm{nM}$. $\left[\mathrm{Ca}^{2+}\right]_{\mathrm{i}}$ further decreased after MIM with $2 \mathrm{mM}$ EGTA was exchanged to SFM with 2 mM EGTA $(b)$.

ally increased to $20 \%$ at $15 \mathrm{~min}$ and $31 \%$ at $30 \mathrm{~min}$ of the control levels during the recovery phase $(n=5)$. These transient changes in $\left[\mathrm{Ca}^{2+}\right]_{i}$ and the intracellular ATP content seemed to be compatible with the previous studies $(31,34,35)$. EGTA (2 mM) completely inhibited the increase in $\left[\mathrm{Ca}^{2+}\right]_{\mathrm{i}}$ during $\mathrm{MI}$ and kept $\left[\mathrm{Ca}^{2+}\right]_{\mathrm{i}}$ at the very low level $(168 \pm 25 \mathrm{nM}$ at 5 min during $\mathrm{MI}$ and $184 \pm 26 \mathrm{nM}$ at $30 \mathrm{~min}$ during MI, $n$ $=3$; Fig. $3, b$ ). We then examined the induction of c-jun mRNA at $60 \mathrm{~min}$ during the recovery phase. With $2 \mathrm{mM}$ EGTA, the levels of c-jun mRNA at 60 min during the recovery phase were significantly reduced as compared with those without EGTA (42\% reduction, $n=3, P<0.01$; Fig. 4). These data suggest that a certain level of $\left[\mathrm{Ca}^{2+}\right]_{\mathrm{i}}$ may be required for the full expression of c-jun mRNA during the recovery phase from $\mathrm{MI}$, although $\left[\mathrm{Ca}^{2+}\right]_{\mathrm{i}}$ may not be essential for the c-jun induction.

Effects of PKC, PKA, and calmodulin kinase on the induction of c-jun mRNA. After the pretreatment of $100 \mu \mathrm{M} \mathrm{H-7}$ or $1 \mu \mathrm{M}$ staurosporine, the induction of c-jun mRNA during the recovery was markedly suppressed in the presence of $100 \mu \mathrm{M}$ $\mathrm{H}-7$ ( $95 \%$ reduction of the levels without $\mathrm{H}-7$ at 60 min during the recovery, $n=3, P<0.01$, Fig. 5 ) or $1 \mu \mathrm{M}$ staurosporine (82\% reduction of the levels without staurosporine at $60 \mathrm{~min}$ during the recovery, $n=3, P<0.01$; Fig. 6.). These data suggest that an activation of PKC may be essential for the cjun induction during the recovery phase after MI. In contrast, the similar treatment of either $10 \mu \mathrm{M} \mathrm{H}-89$ or $10 \mu \mathrm{M} \mathrm{W}-7$ did not influence significantly the expression of c-jun mRNA at 60 min during the recovery from MI (Fig. 6).

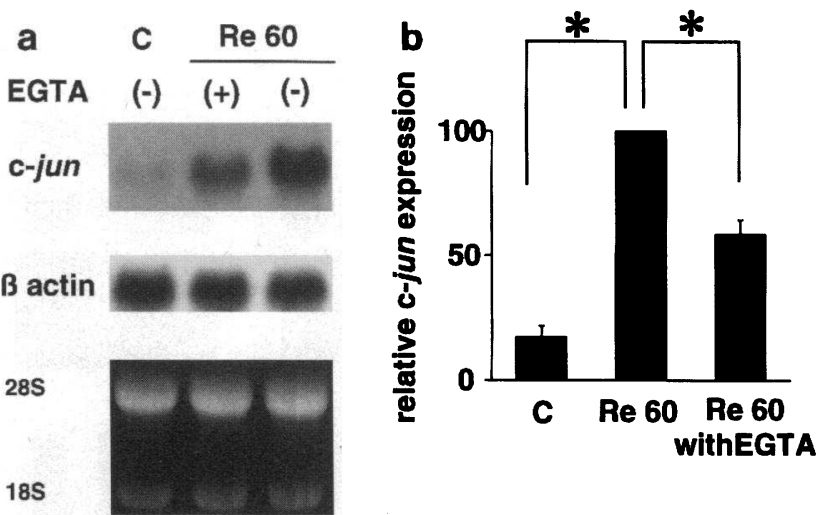

Figure 4. Effect of intracellular $\mathrm{Ca}^{2+}$ on the augmentation of c-jun mRNA expression during the recovery $(R e)$. A representative result of Northern blot analysis shows the expression of c-jun mRNA at $60 \mathrm{~min}$ during Re when treated with $2 \mathrm{mM}$ EGTA or not $(a)$. When $\left[\mathrm{Ca}^{2+}\right]_{\mathrm{i}}$ was prevented from rising and kept below the normal diastolic level during MI and Re with EGTA, the augmentation of c-jun mRNA expression at 60 min during $\operatorname{Re}$ was reduced. The $\beta$-actin signals and the ethidium bromide-stained pictures of $28 \mathrm{~S}$ ribosomal RNAs are shown as internal controls. Densitometric analysis revealed that EGTA significantly reduced the induction of c-jun mRNA by $42 * \pm 6 \%$ at 60 min during $\operatorname{Re}(n=3, * P<0.01)(b)$.

The binding activity in the AP-1 element. EMSA with the ${ }^{32} \mathrm{P}$-labeled oligonucleotide containing the AP-1 element revealed that a single retarded band was observed in all the lanes except the left end lane in Fig. $7 a$. Intensity of the band, representing the DNA binding activity of the nuclear proteins, markedly increased at 120 min during the recovery from MI (Fig. $7 a$ ). As shown in Fig. $7 b$, the specificity of the bindings was examined by competition with excess unlabeled oligonucleotide probes. The binding of the nuclear proteins to the ${ }^{32} \mathrm{P}$ labeled AP-1 element was inhibited in the presence of excess

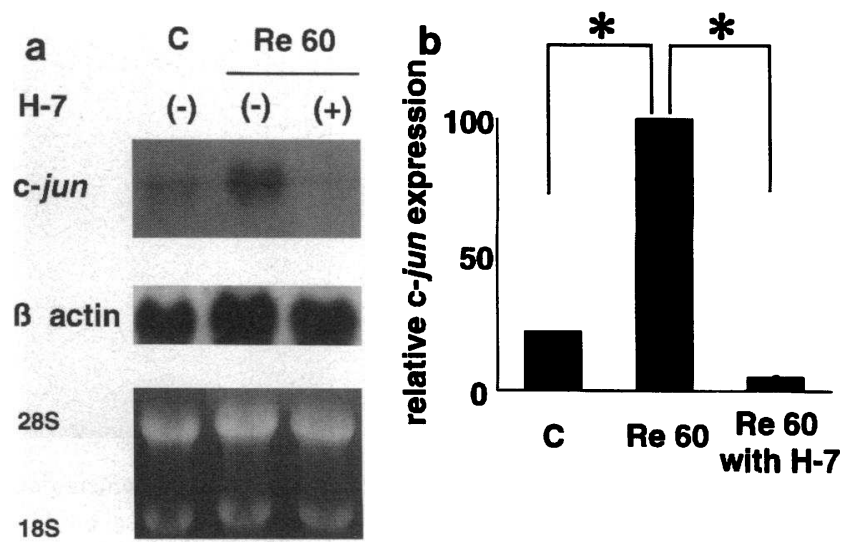

Figure 5. Suppressive effect of a PKC inhibitor, H-7, on the augmentation of c-jun mRNA expression during the recovery $(R e)$. A representative result of Northern blot analysis shows the effect of $\mathrm{H}-7$ on the induction of c-jun mRNA during $\operatorname{Re}(a)$. H-7 $(100 \mu \mathrm{M})$ markedly suppressed the induction of c-jun mRNA at 60 min during Re. The $\beta$ actin signals and the ethidium bromide-stained pictures of $28 \mathrm{~S}$ ribosomal RNAs are shown as internal controls. Densitometric analysis revealed that $\mathrm{H}-7(100 \mu \mathrm{M})$ suppressed the induction of c-jun mRNA by $95^{*} \pm 1 \%$ at 60 min during $\operatorname{Re}(n=3, * P<0.01)(b)$. 


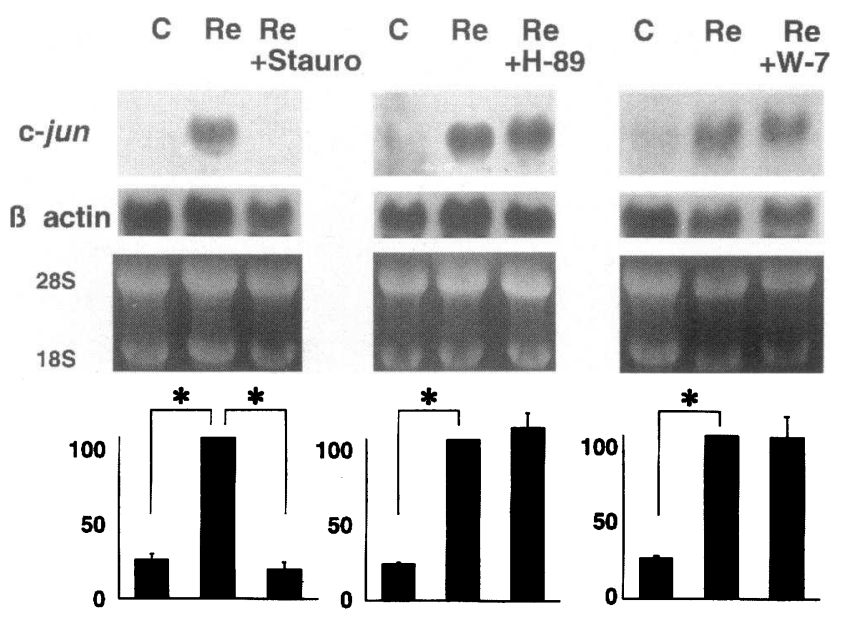

Figure 6. Effects of other protein kinase inhibitors on the augmentation of c-jun mRNA expression during the recovery $(R e)$. Northern blot analysis with densitometric analysis revealed that neither PKA inhibitor, H-89 $(10 \mu \mathrm{M})$, nor calmodulin kinase inhibitor, W-7 (10 $\mu \mathrm{M})$, significantly influenced the induction of c-jun mRNA at 60 min during Re, though another PKC inhibitor, staurosporine (Stauro) of $1 \mu \mathrm{M}$, reduced the induction of c-jun mRNA by $82 * \pm 4 \%$ at 60 min during $\operatorname{Re}(n$ $=3, * P<0.01)$. The $\beta$-actin signals and the ethidium bromide-stained pictures of $28 \mathrm{~S}$ ribosomal RNAs are shown as internal controls.

cold AP-1 probes, but not in the presence of other cold probes including AP-2, AP-3, SP1, and NF1/CTF.

MAP kinase isoform expressed in chicken hearts. Western blot analysis with anti-MAP kinase antibodies showed that isoforms of MAP kinase mainly consisted of $42-\mathrm{kD}$ MAP kinase (Fig. $8 a$ ), as reported in a recent study (36).

MAP kinase activity. The mobility shift assay of MAP ki-

a
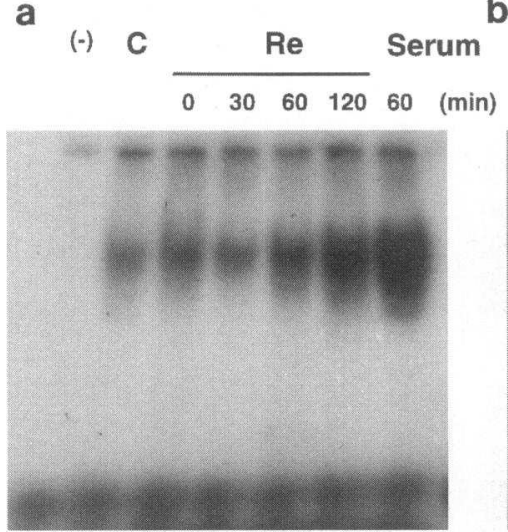

Figure 7. Electrophoretic mobility shift assay of the AP-1 element during the recovery $(\mathrm{Re})$ from metabolic inhibition. The binding activity of AP-1 markedly increased at 120 min during $\operatorname{Re}$ as compared with the control $(C)$ levels $(a)$. In the lane of $(-)$ shown in $a$, the sample containing incubation buffer, labeled AP-1 probes, and bromphenol blue without nuclear protein was loaded. In the lane of Serum 60 in $a$, the nuclear proteins from the cells treated with $20 \%$-serum for $60 \mathrm{~min}$ were loaded as a positive control. As shown in $b$, the binding of nuclear proteins to ${ }^{32} \mathrm{P}$-labeled AP-1 probes at $120 \mathrm{~min}$ during Re was completely inhibited in the presence of excess $(100 \times)$ cold AP-1 probes, but was not significantly affected by other excess $(100 \times)$ cold probes, AP-2, AP-3, SP-1, and NF1/CTF.
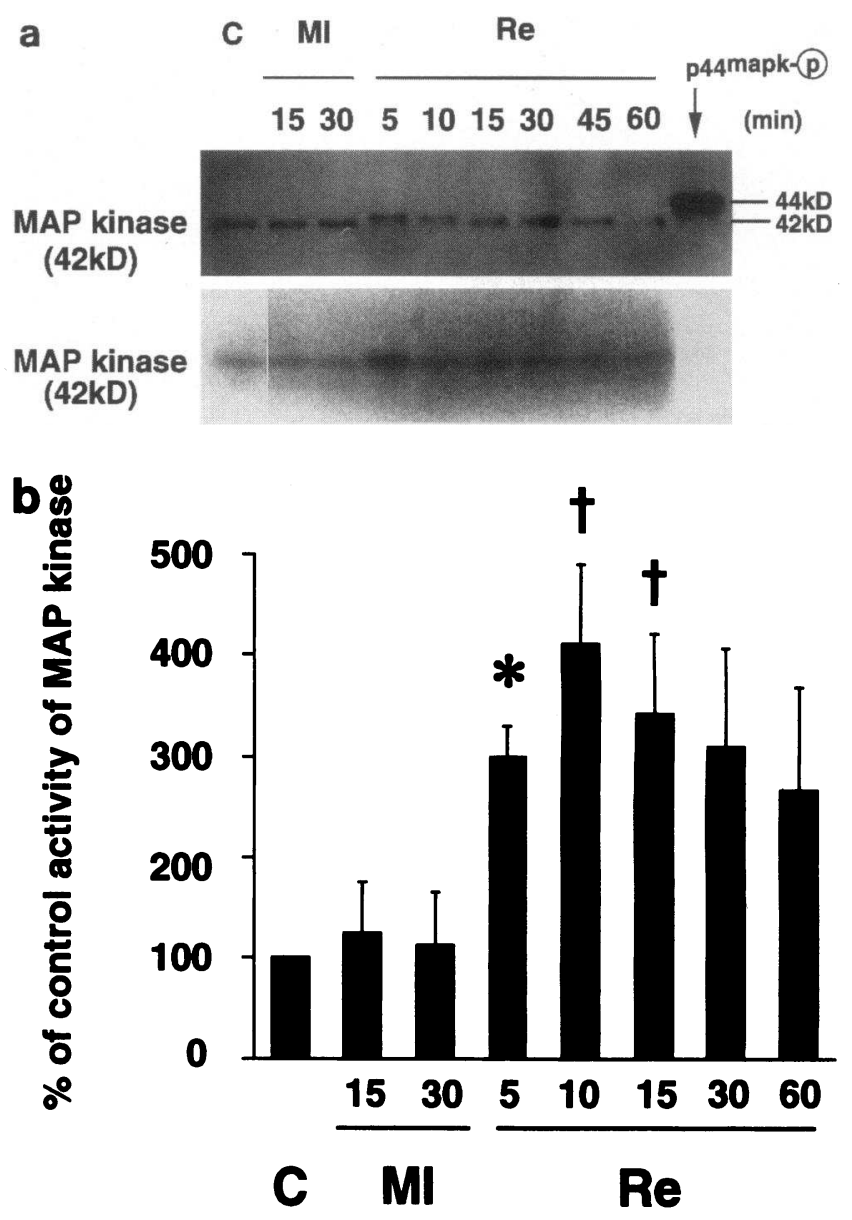

Figure 8. MAP kinase activity during MI and the recovery $(R e)$ from MI. (a) Representative shift mobility assay and in-gel kinase assay of MAP kinase. Western blot with anti-MAP kinase antibody $(a)$ showed that chick embryo cardiac myocytes expressed only 42-kD MAP kinase in the lane of the control sample $(C)$. An arrow in $a$ indicates tyrosinephosphorylated 44-kD MAP kinase (p44 ${ }^{\text {mapk-p }}$ ) purified from sea star (UBI). An additional shifting band appeared from 5 to 30 min during $\mathrm{Re}$, but not during MI $(a)$. The activity of MAP kinase in the in-gel kinase assay was unchanged during MI, but transiently augmented early during $\operatorname{Re}(a)$. (b) Relative activity of MAP kinase by laser densitometry during MI and Re. In-gel kinase assay with laser densitometry has revealed that a significant activation of MAP kinase was observed at 5, 10 , and 15 min during $\operatorname{Re}\left(3.0^{*} \pm 0.3,4.1^{\dagger} \pm 0.8\right.$, and $3.4^{\dagger} \pm 0.8$-fold activity as compared with the control levels, respectively, $n=4 ; * P$ $\left.<0.01,{ }^{\dagger} P<0.05\right)$, though the activity of MAP kinase remained unchanged during $\mathrm{MI}$.

nase with anti-MAP kinase antibody (Fig. $8 a$ ) showed that mobility shifts of the MAP kinase protein were transiently observed from 5 to $15 \mathrm{~min}$ during the recover from MI. In-gel kinase assay of the samples from the same series (Fig. $8 a$, lower panel) also demonstrated that MAP kinase activity transiently increased early during the recovery from MI. Densitometric analysis of the in-gel-kinase assay revealed that MAP kinase activity was significantly augmented at 5,10 , and 15 min during the recovery phase $\left(3.0 * \pm 0.3,4.1^{\dagger} \pm 0.8\right.$, and $3.4^{\dagger} \pm 0.8$-fold increase compared with the control levels, respectively, $n=4$, ${ }^{*} P<0.01,{ }^{\dagger} P<0.05$, Fig. $8 b$ ), although it remained unchanged during MI. These data suggest that $42-\mathrm{kD}$ MAP kinase was transiently activated early during the recovery from MI. 


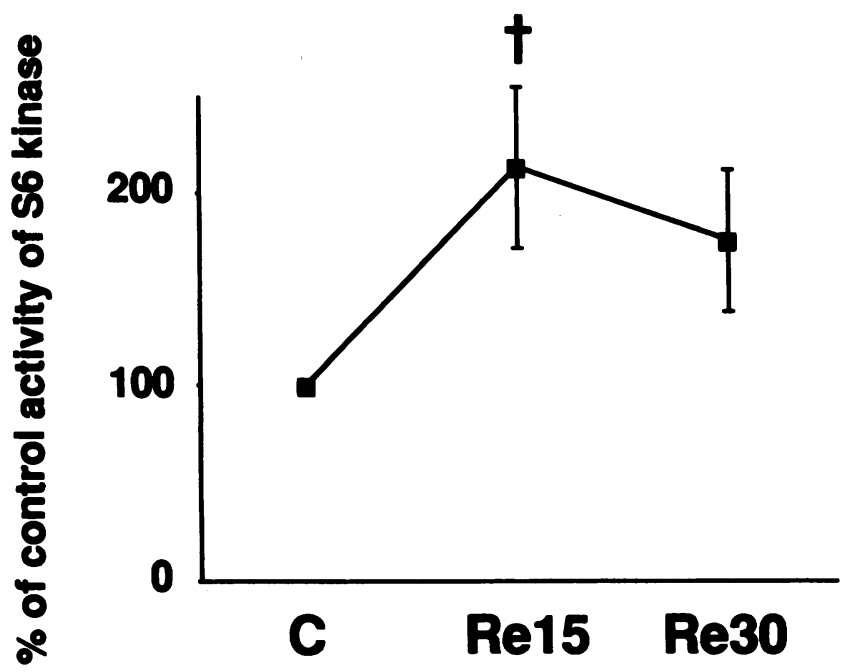

Figure 9. S6 kinase activity during the recovery $(R e)$ from metabolic inhibition. The phosphorylation of S6 peptide was augmented at $15 \mathrm{~min}$ during $\operatorname{Re}\left(2.1^{\dagger} \pm 0\right.$.4-fold increase compared with the control level, $n$ $=4,{ }^{\dagger} P<0.05$ ).

S6 peptide kinase activity. As shown in Fig. 9., S6 kinase, pRSK90, was significantly activated at 15 min during the recovery from MI (2.1 \pm 0.4 -fold increase as compared with the control levels, $n=4, P<0.05$ ).

\section{Discussion}

The present study has revealed that both the expression of IE gene mRNAs and the activity of MAP kinase were augmented, not during MI, but during the recovery from MI. The induction of c-jun mRNA was shown to depend on the activation of PKC, and to some extent, on intracellular $\mathrm{Ca}^{2+}$. The time course of the MAP kinase activation preceded that of IE gene induction. To our knowledge, this is the first study that demonstrated the association between the recovery from MI (a model of myocardial reperfusion) and the induction of $\mathrm{IE}$ genes as well as the activation of protein kinase cascades, which have been assumed as early signals for myocardial hypertrophy.

According to recent studies $(22,23)$, IE genes could be induced without reperfusion or reoxygenation. Furthermore, a more recent study (37) revealed that IE genes were induced during $\mathrm{MI}$ in neonatal rat cardiac myocytes. Although precise reasons for the differences between this previous study and ours are not fully elucidated, one reason may be the difference of the intracellular ATP level during MI. In our model, the ATP level rapidly decreased to $10 \%$ of the control level at $15 \mathrm{~min}$ during MI and remained below this low level throughout MI. In contrast, ATP only decreased to $20-30 \%$ of the control level and did not decrease below that level for 6 hours during MI when $1 \mathrm{mM} \mathrm{KCN}$ and $20 \mathrm{mM}$ 2-deoxy-d-glucose were used in neonatal rat cardiac myocytes (37). In our model, the ATP levels recovered to $21 \%$ at $15 \mathrm{~min}$ and $31 \%$ at $30 \mathrm{~min}$ of the control levels during the recovery from MI. It is possible that even in our model early signals might have been transmitted to the intracellular pathways during MI, but were not converted to the induction of IE genes because of more severe energy depletion.

As to the signal transduction pathways leading to the induc- tion of c-jun, our results demonstrated that PKC played a main role. $\left[\mathrm{Ca}^{2+}\right]_{i}$ might also contribute to its induction to some extent, although we could not specify the way how $\left[\mathrm{Ca}^{2+}\right]_{\mathrm{i}}$ contributed to the induction. One possible mechanism is that $\left[\mathrm{Ca}^{2+}\right]_{\mathrm{i}}$ may influence the $\mathrm{c}$-jun induction via Ca-calmodulin kinases, which are activated by calcium-calmodulin complex. Another one is that $\left[\mathrm{Ca}^{2+}\right]_{\mathrm{i}}$ may play a role via the activation of the $\mathrm{Ca}^{2+}$-dependent isoforms of PKC. These isoforms can be maximally activated only in the presence of intracellular calcium ion. H-7 of $100 \mu \mathrm{M}$ and staurosporine of $1 \mu \mathrm{M}$ are both supposed to be enough to completely suppress the activity of PKC, but might affect the activities of other kinases such as PKA and calmodulin kinases. Neither H-89 (10 $\mu \mathrm{M})$ nor W-7 $(10 \mu \mathrm{M})$, however, changed the levels of c-jun mRNA at 60 min during the recovery from MI. These data also support the role of PKC for the induction of c-jun mRNA during the recovery. To clarify this point, further studies using specific inhibitory peptides will be needed.

The c-jun and c-fos genes are known to belong to a group of AP-1 genes, which enhance the expression of various genes by dimerizing and binding to the AP-1 sites in their promoters. In our model, we demonstrated that the binding activity of AP1 element markedly increased at 120 min during the recovery from MI. Thus, the induction of the c-jun and c-fos genes during the recovery phase after MI implies that a series of IE genes are transcribed during the recovery and then contribute to the transcription of various cardiac and other IE genes as transcription factors, such as AP-1 proteins. A previous study has demonstrated that adrenergic stimulation augmented the expression of IE genes, such as c-jun, c-fos, and egr-1, and that this stimulation also plays an important role in the accumulation of the myosin light chain-2 in rat cardiac myocytes (15). On the other hand, another study reported that with CAT assay and gel-shift assay of the promoter region of the atrial natriuretic peptide gene, which contains an AP-1 elements, the promoter activity was influenced by c-Jun and c-Fos activities in neonatal cardiac myocytes (17). Although which cardiac or IE genes are directly activated by c-jun or c-fos product remains to be clarified, the induction of these mRNA species seems to be one of the first among the serial gene activation during the recovery phase after MI. To further investigate the role of AP-1 proteins in the recovery process after MI, CAT assay of certain cardiac or IE gene will be needed both during and after MI.

Our study has demonstrated that MAP kinase activity was also augmented only during the recovery from MI. In other types of cultured cells, MAP kinase was generally considered to mediate proliferation and microtubulus stability in $\mathbf{M}$ phase $(29,35)$. However, in cardiac myocytes that lost the ability to proliferate, the role of MAP kinase in their function remained uncertain. A recent in vitro study (29) suggested that MAP kinase seemed to play an important role in myocardial hypertrophic processes, probably by accelerating protein synthesis and regulating the function of the transcriptional factors. Thus, the increase in MAP kinase activity might have a supportive effect on the repair and reproduction of cellular components by activating S6 kinase, which is suggested to accelerate the protein synthesis. In fact, we observed an increase in S6 kinase activity during the recovery from MI in the present study. Moreover, MAP kinase is known to positively regulate the activity of the specific promotor regions such as AP-1 site and serum response element by phosphorylating c-Jun (39) and Elk-1 (40), respectively. These data may support a hypothesis that the activation 
of MAP kinase in cardiac myocytes may be one of the important molecular events underlying the recovery from MI. The relationship between MAP kinase activation and change in $\left[\mathrm{Ca}^{2+}\right]_{\mathrm{i}}$ may be another important point in this model. A recent study (41) has revealed that $\left[\mathrm{Ca}^{2+}\right]_{i}$ is essential for activation of MAP kinase. In our study, the increase in $\left[\mathrm{Ca}^{2+}\right]_{i}$ during $\mathrm{MI}$ might play a role in the MAP kinase activation during the recovery from MI.

In this study, we used the in vitro MI model of chick embryo ventricular myocytes as a model of myocardial ischemia for the following reasons. First, this model has repetitively been used to study cell physiology, intracellular ion homeostasis, and energy metabolism in detail $(42,43)$. Second, Ikenouchi et al. (44) and we (45) previously reported that this cell culture contained negligible amounts of nonmyocytes, and we can therefore neglect the effects of the contaminating cells. Third, in cultured cells, the effect of mechanical stress may be negligible. On the other hand, limitations of the present study may also be related to the use of this "in vitro" model. This kind of "in vitro" cell culture model usually represents only a partial aspect of "in vivo" pathophysiological processes. We believe, however, that our results can be reasonably extended to "in vivo" ischemia, because our "in vitro" model represents one of the most essential aspects of ischemia, that is, energy depletion.

We conclude that in cardiac myocytes the induction of IE genes and MAP kinase activation seem to play roles in the recovery of cardiac myocytes from a brief period of MI. Our "in vitro" model of metabolic inhibition/recovery will be feasible for more detailed study of molecular mechanisms underlying ischemia/reperfusion process.

\section{Acknowledgments}

We thank Miss Y. Kozawa for her technical assistance, Dr. H. Iba for supplying pfosRPA plasmid, Mr. K. Kimura and Dr. Y. Fukui for their technical assistance, Dr. H. Ikenouchi for his technical assistance for ATP measurement, and Dr. M. Sata for his assistance in setting up the high performance liquid chromatography equipment.

This study was supported in part by Grant-in -Aids ( 04670518 for T. Takahashi, and 05857080 for T. Aoyagi) from the Ministry of Education, Culture and Science of Japan.

\section{References}

1. Pfeffer, M. A., and E. Braunwald. 1990. Ventricular remodeling after myocardial infarction. Circulation. 81:1161-1172.

2. Ertl, G., P. Gaudron, and K. Hu. 1993. Ventricular remodeling after myocardial infarction. Experimental and clinical studies. Basic. Res. Cardiol. 88 (suppl 1):125-137

3. Virmana, R., J. B. Atkinson, and J. J. Fenoglio. 1991. Cardiovascular pathology. W. B. Saunders company, Philadelphia, PA. 91-98.

4. Hess, O. M., J. Schneider, H. Nonogi, J. D. Carroll, K. Schneider, M. Turina, and H. P. Krayenbuehl. 1988. Myocardial structure in patients with exercise-induced ischemia. Circulation. 77:967-977.

5. Schneider, M. D., and T. G. Parker. 1990. Cardiac myocytes as targets for the action of peptide growth factors. Circulation. 81:1443-1456.

6. Schunkert, H., L. Jahn, S. Izumo, C. S. Apstein, and B. H. Lorell. 1991. Localization and regulation of c-fos and c-jun protooncogene induction by systolic wall stress in normal and hypertrophied rat hearts. Proc. Natl. Acad. Sci. USA. 88:11480-11484

7. Takahashi, T., H. Schunkert, S. Isoyama, J. Y. Wei, B. Nadal-Ginard, W. Grossman, and S. Izumo. 1992. Age-related differences in the expression of protooncogene and contractile protein genes in response to pressure overload in the rat myocardium. J. Clin. Invest. 89:939-946.

8. Komuro, I., M. Kurabayashi, F. Takaku, and Y. Yazaki. 1988. Expression of cellular oncogenes in the myocardium during the developmental stage and pressure-overloaded hypertrophy of the rat heart. Circ. Res. 62:1075-1079.

9. Sadoshima, J., and S. Izumo. 1993. Mechanical stretch rapidly activates multiple signal transduction pathways in cardiac myocytes: potential involvement of an autocrine/paracrine mechanism. EMBO (Eur. Mol. Biol. Organ) J. 12:1681-1692.

10. Starksen, N. F., P. C. Simpson, N. Bishopric, S. R. Coughlin, W. M. F. Lee, J. A. Escobedo, and L. T. Williams. 1986. Cardiac myocyte hypertrophy is associated with c-myc protooncogene expression. Proc. Natl. Acad. Sci. USA. 83:8348-8350.

11. Chiu, R., W. J. Boyle, J. Meek, T. Smeal, T. Hunter, and M. Karin. 1988. The c-Fos protein interacts with c-Jun/AP-1 to stimulate transcription of AP-1 responsive genes. Cell. 54:541-551.

12. Angel, P., K. Hattori, T. Smeal, and M. Karin. 1988. The jun protooncogene is positively autoregulated by its product, Jun/AP-1. Cell. 55:875-885.

13. Harazonetis, T.D., K. Georgopoulos, M. E. Greenberg, and P. Leder. 1988. c-Jun dimerizes with itself and with c-Fos, forming complexes of different DNA binding affinities. Cell. 55:917-924.

14. Bishopric, N. H., V. Jayasena, and K. A. Webster. 1992. Positive regulation of the skeletal alpha-actin gene by Fos and Jun in cardiac myocytes. J. Biol. Chem. 267 (35):25535-25540.

15. Iwaki, K., V. P. Sukhatme, H. E. Shubeita, and K. R. Chien. 1990. $\alpha$ and $\beta$-adrenergic stimulation induces distinct patterns of immediate early gene expression in neonatal rat myocardial cells. J. Biol. Chem. 265:13809-13817.

16. Rosenzweig, A., T. D. Halazonetis, J. G. Seidman, and C. E. Seidman. 1991. Proximal regulatory domains of rat atrial natriuretic factor gene. Circulation. 84:1256-1265

17. Kovacic-Milivojevic, B., and D. G. Gardner. 1992. Divergent regulation of the human atrial natriuretic peptide gene by c-jun and c-fos. Mol. Cell. Biol. 12:292-301.

18. Kim, S., P. Angel, R. Lafyatis, K. Hattori, K. Y. Kim, M. B. Sporn, M. Karin, and A. B. Roberts. 1990. Autoinduction of transforming growth factor $\beta 1$ is mediated by the AP-1 complex. Mol. Cell. Biol. 10:1492-1497.

19. Nowak, Jr., T.S., J. Ikeda, and T. Nakajima. 1990. 70-kDa heat shock protein and c-fos gene expression after transient ischemia. Stroke. 21 (suppl III): III-107-III-111.

20. Ouellette, A. j., R. A. Malt, V. P. Sukhatme, and J. V. Bonventre. 1990. Expression of two "immediate early genes," EGR-1 and c-fos, in response to renal ischemia and during compensatory renal hypertrophy in mice. J. Clin. Invest. 85:766-771.

21. Scott, K.V.W., S. M. Andrea, T. Gunilla, Z. Xiao-Hong, K. Michael, and J. S. Norman. 1994. Activation of heat-shock transcription factor by graded reductions in renal ATP, in vivo, in the rat. J. Clin. Invest. 94:1518-1523.

22. Brand, T., H. S. Sharma, K. E. Fleischmann, D. J. Duncker, D. E. McFalls, P. D. Verdouw, and W. Schaper. 1992. Proto-oncogene expression in porcine myocardium subjected to ischemia and reperfusion. Circ. Res. 71:1351-1360.

23. Webster, K. A., D. J. Discher, and N. H. Bishopric. 1993. Induction of nuclear accumulation of fos and jun proto-oncogenes in hypoxic cardiac myocytes. J. Biol. Chem. 268:16852-16858.

24. Barry, W. H., G. A. Peeters, C. A. F. Rasmussen, Jr., and M. J. Cunningham. 1987. Role of changes in $\left[\mathrm{Ca}^{2+}\right]_{\mathrm{i}}$ in energy depletion contracture. Circ. Res. 61:726-734.

25. Chomczynski, P., and N. A. Sacchi. 1987. Single step method of RNA isolation by guanidinium thiocyanate-phenol extraction. Anal. Biochem. 162:156159.

26. Suzuki, T., M. Murakami, N. Onai, E. Fukuda, Y. Hashimoto, M. H. Sonobe, T. Kameda, M. Ichinose, K. Miki, and H. Iba. 1994. Analysis of AP-1 function in cellular transformation pathways. J. Virol. 68:3527-3535.

27. Schreiber, E., P. Matthias, M. M. Muller, and W. Schaffner. 1989. Rapid detection of octamer binding proteins with 'mini-extracts', prepared from a small number of cells. Nucleic Acids Res. 17:6419.

28. Gotoh, Y., E. Nishida, M. Kawakami, and H. Sakai. 1990. Microtubulusassociated-protein (MAP) kinase activated by nerve growth factor and epidermal growth factor in PC12 cells. Identity with the mitogen-activated MAP kinase of fibroblastic cells. Eur. J. Biochem. 193 (3):661-669.

29. Yamazaki, T., K. Tobe, E. Hoh, K. Maemura, T. Kaida, I. Komuro, H. Tametomo, T. Kadowaki, R. Nagai, and Y. Yazaki. 1993. Mechanical loading activates mitogen-activated protein kinase and S6 peptide kinase in cultured rat cardiac myocytes. J. Biol. Chem. 268:12069-12076.

30. Kohmoto, O., H. Ikenouchi, Y. Hirata, S. Momomura, T. Serizawa, and W. H. Barry. 1993. Variable effects of endothelin-1 on $\left[\mathrm{Ca}^{2+}\right]_{i}$ transients, $\mathrm{pH}_{\mathrm{i}}$, and contraction in ventricular myocytes. Am. J. Physiol. 265:H793-H800.

31. Ikenouchi, H., O. Kohmoto, M. McMillan, and W. H. Barry. 1991. Contributions of $\left[\mathrm{Ca}^{2+}\right]_{i},\left[\mathrm{P}_{\mathrm{i}}\right]_{\mathrm{i}}$, and $\mathrm{pH}_{\mathrm{i}}$ to altered diastolic myocyte tone during partial metabolic inhibition. J. Clin. Invest. 88:55-61.

32. Sellevold, O. F. M., P. Jynge, and K. Aarstad. 1986, High performance liquid chromatography. A rapid isocratic method for determination of creatinine compounds and adenosine nucleotides in myocardial tissue. J. Mol. Cell. Cardiol. 18:517-527.

33. Lowry, D.H., N. J. Rosenbrough, A. L. Farr, and R. J. Randall. 1951. Protein measurement with Folin phenol reagent. J. Biol. Chem. 193:265-275.

34. Kohmoto, O., and W. H. Barry. 1989. Mechanism of protective effects of 
$\mathrm{Ca}^{++}$channel blockers on energy deprivation contracture in cultured ventricular myocytes. J. Pharmacol. Exp. Ther. 248:871-878.

35. Shiina, N., T. Moriguchi, K. Ohta, Y. Gotoh, and E. Nishida. 1992 Regulation of a major microtubule-associated protein by MPF and MAP kinase EMBO (Eur. Mol. Biol. Organ.) J. 11:3977-3984.

6. Chils, T. J., M. H. Watson, J. S. Sanghera, D. L. Campbell, S. L. Pelech, and A. S. Mak. 1992. Phosphorylation of smooth muscle caldesmon by mitogenactivated protein (MAP) kinase and expression of MAP kinase in differentiated smooth muscle cells. J. Biol. Chem. 267:22853-22859.

37. Webster, K. A. D. J. Discher, and N. H. Bishopric. 1994. Regulation of fos and jun immediate-early genes by redox or metabolic stress in cardiac myocytes. Circ. Res. 74:679-689.

38. Ishida, H., O. Kohmoto, J. H. Bridge, and W. H. Barry. 1988. Alterations in cation homeostasis in cultured chick ventricular cells during and after recovery from adenosine triphosphate depletion. J. Clin. Invest. 81:1173-1181.

39. Pulverer, B. J., J. M. Kyriakis, J. Avruch, E. Nikolakaki, and J. R. Woodgett. 1991. Phosphorylation of c-jun mediated by MAP kinases. Nature (Lond.). 353:670-674.

40. Marais, R., J. Wynne, and R. Treisman. 1993. The SRF accessory protein
Elk-1 contains a growth factor-regulated transcriptional activation domain. Cell. 73(2):381-393.

41. Sadoshima, J., Z. Qiu, J. P. Morgan, and S. Izumo. 1995. Angiotensin II and other hypertrophic stimuli mediated by $G$ protein-coupled receptors activated tyrosine kinase, mitogen-activated protein kinase, and 90-kD S6 kinase in cardiac myocytes. Circ. Res. 76:1-15.

42. Eisner, D. A., C. G. Nichols, S. C. O'Neill, G. L. Smith, and M. Valdeolmillos. 1989. The effect of metabolic inhibition on intracellular calcium and $\mathrm{pH}$ in isolated rat ventricular cells. J. Physiol. 411:393-418.

43. Esumi, K. M. Nishida, D. Shaw, T. W. Smith, and J. D. Marsh. 1991. NADH measurements in adult rat myocytes during simulated ischemia. Am. J. Physiol. 260:H1743-H1752.

44. Ikenouchi, H., L. Zhao, M. McMillan, E. M. Hammond, and W. H. Barry. 1993. ATP depletion causes a reversible decrease in $\mathrm{Na}^{+}$pump density in cultured ventricular myocytes. Am. J. Phisiol. 264:H1208-H1214.

45. Kinugawa, K., T. Takahashi, O. Kohmoto, A. Yao, T. Aoyagi, S. Momomura, Y. Hirata, and T. Serizawa. 1994. Nitric oxide-mediated effects of interleukin 6 on $\left[\mathrm{Ca}^{2+}\right]_{\mathrm{i}}$ and cell contraction in cultured chick ventricular myocytes. Circ. Res. 75:285-295. 